\title{
Blurred borders. Entrepreneurial activity of Poles in Germany in the eyes of experts
}

The inspiration for this article is the increasing number of businesses being established by Poles in Germany, especially in the eastern part of the country. The authors' aim is to research the strategies of Polish entrepreneurs behind the western border and to point out the forms of their participation in the German labor market. We base our narrative on individual interviews with the experts in the field of transnational entrepreneurship, and we discuss the motivations and the competitive advantages of Polish entrepreneurs. We describe their barriers and reflect on the future of Polish entrepreneurship in Germany. As the context, we employ sociological theories relevant in the field of migrations and entrepreneurship and look at statistical data illustrating the activity of Polish entrepreneurs in the Polish-German cross-border area. We answer questions about their ways of functioning there from the viewpoint of representatives of companies, institutions and organizations supporting them. In the article, we base our findings on the knowledge, opinions and predictions of our experts.

Keywords: cross-border entrepreneurship, migrations, labor market, economic sociology, social capital

\section{Introduction}

Migration of Poles to Germany has a long history. Geographical proximity, differences in levels of economic development, and institutional and political changes in both territories have always influenced the flow, scope and waves of migration

${ }^{1}$ Corresponding author: Maria Nawojczyk, maria@list.pl 
of Poles to Germany. Since the accession of Poland to the European Union in 2004 and the openness of German job market to Polish workers since 2011 (Koźbiał 2015) we observe particularly favorable conditions for the flow of people and businesses across the Polish-German border. ${ }^{2}$ This long history of Polish migration to Germany provides the opportunity to observe different types of entrepreneurship: migration entrepreneurship, ethnic entrepreneurship and transnational entrepreneurship, following the categories described in the literature (see, e.g., Brzozowski, Cucculelli and Surdej 2014). In this article, we discuss the forms of participation of Polish entrepreneurs on the German labor market and show how it has changed over the years. We present the strategies of Polish entrepreneurs (both men and women; in this article we do not distinguish between experiences of male-run and female-run Polish companies in Germany) which are dependent on both the business sectors in which they set up their enterprises and on the size of the undertaking. In our analyses we follow the well-described traits concerning advantages and disadvantages of migrant entrepreneurship, and the positions of migrants on the job market in the receiving country (see, e.g., Ram, Jones and Vilares-Varela 2017; Kloosterman and Rath 2001). We also propose an interpenetration of their personal (individual) and occupational strategies as based on the mixed culture of the country of origin and the environment of the receiving country (ForemanPeck and Zhou 2013, Kloosterman 2010). We analyze the competitive advantages of Poles that allow them to fill gaps in the German labor market (Nowicka 2013). We take a closer look at the obstacles that are encountered by Polish entrepreneurs on the western border of Poland, pointing out that political and legal regulations on both sides of the Polish-German border are important migration triggers (Ram, Jones and Vilares-Varela 2017; Foreman-Peck and Zhou 2013).

Economic sociology offers many insights useful for the study of migrant entrepreneurship. Many concepts and categories are taken from general theories of entrepreneurship, but they seem to be well applicable to this specific field of research. We have here in mind the pulling and pushing factors as motivators of entrepreneurial activity (Aldrich 2005, Aldrich and Martinez 2003; Lin and Tao 2012). We treat entrepreneurship as a way of actively shaping one's life (particularly with regards to one's career) in highly uncertain circumstances (Foreman-Peck and Zhou 2013; Aldrich 2005, Reynolds 1991). Many sociological theories of entrepreneurship focus directly on ethnic or migration entrepreneurs (see, e.g., Bonacich 1973, Portes and Zhou 1992), who stress the problems of closed or limited channels of upward social mobility of migrants as the main trigger for establishing their own businesses (Waldinger, Aldrich and Ward 1990; Brzozowski, Cucculelli and Surdej 2014). Today, such factors as favorable market conditions (structural

\footnotetext{
${ }^{2}$ For a detailed description of the border region considering the entrepreneurial activity of Poles in Germany, see Skraba and Nowicka in the same volume.
} 
and cultural conditions), access to property (possibility of legally holding an established company), opportunities to enhance individual predispositions (access to education) and the ability to mobilize resources (creating a network) are the grounds for a great diversity of ethnic entrepreneurship, depending on the nature of individual ethnic groups and the social contexts of their functioning (Kloosterman and Rath 2003; Nowicka 2013). The studies on migrant entrepreneurship are becoming more and more focused on transnational entrepreneurship due to globalization processes (Brzozowski, Cucculelli and Surdej 2014; Aliaga-Isla and Rialp 2013).

\section{Methodology}

On the Polish side of the border less data to describe migration processes are available than on the German side. Even though there still is a shortage of reliable and complete data concerning migration of entrepreneurs and entrepreneurship of migrants, some figures are worth presenting here. Considering the data from the last five years, one sees that the number of companies in Poland is increasing by the year. However, in the area of special interest to us, the Lubusz and West Pomeranian Voivodships (both in the western part of Poland), we observe a slight but permanent decrease in the scope of emergent economy activities, including these registered in the KRS (National Court Registry) system. The line graph below compares the new firms in those two voivodships with the background of Poland at large. For simplicity's sake, the sole proprietorships, partnerships and other business entities registered with the KRS were included.

Yet even more about the shape of Polish enterprises can be found in the data on the registered business activities and firms that were not active, or which were subject to bankruptcy procedures. Especially interesting for us in this context are the data concerning the construction sector, one of the two industries researched in our project (the other sector of concern is IT). In the ranking of bankruptcy proceedings, when broken down by industries, activity identified as "construction work associated with the raising of residential and non-residential buildings" is in first place, while "realization of construction projects relevant to the erecting of buildings" comes in second. As many as $16.44 \%$ of all bankruptcy proceedings are pending against the representatives of the construction sector. The figures reflecting proceedings for dissolving companies provide similar information. The construction sector leads the way here as well: in 2017 as many as 760 businesses handling building works were pending dissolution. These data allow us to assume that the Polish entrepreneurs operating in the border area are increasingly turning away from doing business in Poland, and are attempting to reach the western markets. 
Number of economic activities registered yearly

Line graph 1.

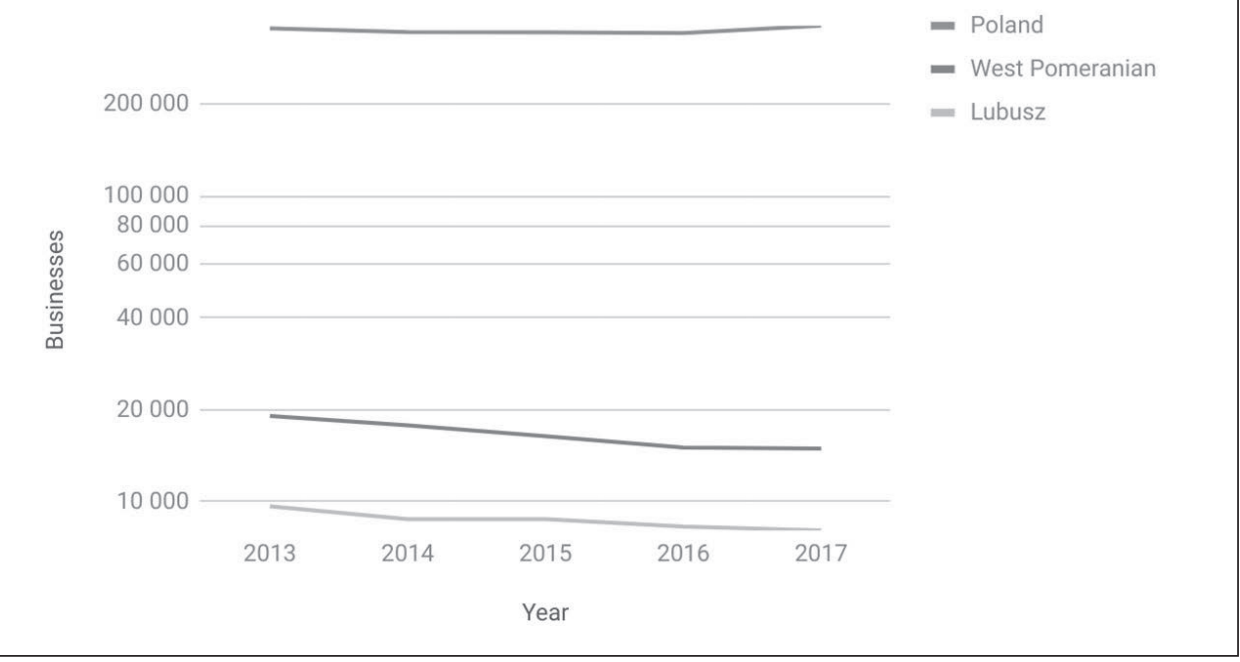

Source: based on http://www.coig.com.pl/ (accessed 19/07/2018)

Other interesting data concern foreign investors in Poland. Both Szczecin and Zielona Góra - the capitals of the West Pomeranian and the Lubusz Voivodships - belong to those Polish cities in which there are at least 50 registered firms with foreign capital. Among the industries in which investors from abroad place their money particularly often are, again, "construction work associated with the erecting of residential and non-residential buildings" and "realization of construction projects relevant to the raising of buildings". In the ranking of new firms with foreign capital, construction companies are in second place, as they make up $11.67 \%$ of the companies in question. Szczecin and Zielona Góra are also included in the ranking of Polish cities that are business friendly, compiled annually by The AllPolish Centre of Economic Information (see: http://www.coig.com.pl/ [accessed 19/07/2018]), with Szczecin in eighth place and Zielona Góra ranking third. These were exactly the cities in which we recruited our experts for interviewing.

In our research project we have been studying the phenomenon of Polish migrant entrepreneurship in the German regions bordering Poland through individual interviews with migrants and local experts on both sides of the border. ${ }^{3}$

${ }^{3}$ This research has been made possible by funding from the German-Polish Science Foundation (Polsko-Niemiecka Fundacja na Rzecz Nauki/Deutsch-Polnische Wissenschaftsstiftung) for the project "Europäisierung der Lebenslagen. Polnische Gründer/innen in Berlin und im Deutsch-Polnischen Grenzgebiet” (2016-2018). 
In this article we will be referring to material based on in-depth interviews with local experts. The interviews were conducted in the Polish-German cross-border area. In Poland, in the above-mentioned two biggest cities of West Pomerania and Lubusz, and in Germany in the following cities: Berlin, Schwedt (Oder), Frankfurt (Oder), Potsdam, Strasburg and Pasewalk. We collected the research material from November 2016 to April 2017. We approached representatives of public and private institutions and associations monitoring and supporting entrepreneurial activity of Poles in Germany, located in Polish western voivodships and German eastern lands. To get through to our experts we used different paths and reasoning: we included officials of local government institutions established for Polish-German cooperation who, we thought, should have knowledge about migration issues, and legal advisors and tax advisors helping entrepreneurs with their economic activity - referred to us both by local government officials as well as by entrepreneurs we also interviewed. ${ }^{4}$ In this article, we used 16 in-depth interviews with the owners or high-ranking employees of those institutions, whom we considered the experts, among them 13 men and 3 women. They are the people who, in their daily professional activities, deal with Poles self-employed in Germany. Thus they became for us the source of information on the current challenges and functioning of their clients on the German labor market. More than once we have used snowball sampling when recruiting respondents. Their factual knowledge, opinions, suggestions and forecasts form the empirical basis of our article.

\section{The model of analysis}

One of the research problems concerns the motivations of Poles to set up an enterprise in Germany, and the reasons why they find this country attractive. We had assumed that the economic and geographical motivations were major determinants of the decisions to emigrate. We also asked the experts about the ways the Polish entrepreneurs function in the German cross-border area, and the strategies of managing firms in the neighboring country which they had chosen. In the interviews, we were interested in the influence of the various legal regulations on the growth of Polish entrepreneurship, the overall relationships between Poles and Germans, and the predicted futures of the companies in question. Another aim of the research was to check the hypothesis, widely accepted in Poland, about the ignorance of Poles in Germany regarding the German regulations, and the language barrier as the main obstacles in the development of the Polish entrepreneurship in eastern regions of Germany.

\footnotetext{
${ }^{4}$ The research material from interviews of individual entrepreneurs, Poles having businesses in Germany, is not included in this article.
} 
Analyzing the problems mentioned above, we are proposing to explain our findings using the model (presented below) of conditions in which one is willing to take risks that lead to entrepreneurial opportunities.

Figure 2.

Model of entrepreneurial opportunities

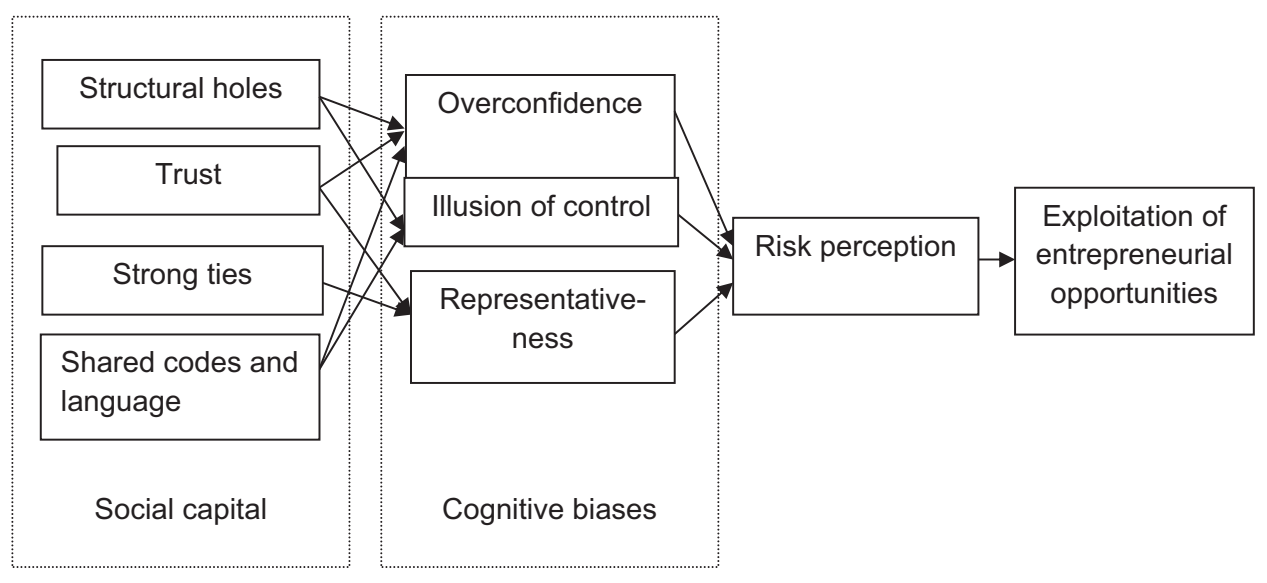

Source: De Carolis and Saparito 2006

An interconnection between social capital and cognitive biases is, according to this model, necessary for taking advantage of new business opportunities. Below, we intend to show how these resources (capital) and biases work in the context of entrepreneurial activity of Poles in Germany, who are sometimes described as "swinging migrants" (Garsztecki 2016). So, the question is: why are Poles drawn to establishing businesses in Germany?

The main factor that differentiates work in Germany and in Poland is wages. The earnings gained from the sale of products or services in Germany are much higher than in Poland. Economic motivation is most often mentioned when asked about reasons for migration.

The profits they can achieve by comparing what they are able to receive as prices for their products on the Polish and German markets is certainly in favor of these profits from the German side. [R3]

Many Poles arrived in Germany when the overall political and economic situation in Poland hardly provided means for individual enrichment. The western neighbor was chance to improve the individual's material standing and prospects for the future, and the Polish-German borderline became a gateway to a "consumer's paradise". 
Trivial factors like very small geographical distance are not meaningless either. The proximity of Berlin and other cities in eastern Germany allows Poles to maintain regular contact with family and friends in their home country. When they have a choice between Berlin and other western European capitals (such as London), they decide to move closer to home. Many Polish cities, especially in western voivodships, are better connected with Berlin than with Warsaw or Cracow. Entrepreneurs, according to our experts, tend to emphasize this "ecological" factor when they talk about reasons for of running a business there.

It seems to me that this interaction, through geographic proximity, nothing more, will be strongest right here on the border, and this interaction additionally strengthens, ... some small-neighborly relations are established, right? Resulting simply from geographical proximity. [R1]

All the experts, in every interview, point out the vast influence of political events, internal and external, on Polish entrepreneurship. Opening of Polish borders, joining the European Union, and the liberalization of the German labor market: these are the major moments that made it possible for Poles to establish economic activity abroad; they opened up legal opportunities for Polish entrepreneurs to widen the scope of their companies to include foreign markets. Regulations concerning the free movements of people and goods within the European Union has had a specific meaning in this context.

The year 2004 was a breakthrough ... You do not need visas, there is no control, free movement of people and goods. Now a Pole is driving a car, buying material in Szczecin, where it is still cheaper than in Germany, loading it and going to Germany. Without this, no Polish enterprise in Germany would exist. It would not have been possible, for example, for legal reasons, it was not allowed. [R7]

Since the entry to the European Union, the construction industry has been growing significantly, because there are no such restrictions resulting from work permits. [R8]

\section{Social capital of Polish entrepreneurs in Germany}

The first and the paramount issue connected with the social capital of migrant entrepreneurs is their shared communication codes, basically language. Those can be used as advantages in business activity when somebody is bilingual, but they could be also obstacles when the skills to communicate in a foreign language are inadequate.

Many Polish entrepreneurs in Germany work in the framework of sole proprietorship, so they are the owners and the only employed person in their company. Those who need other employees mostly hire Poles. The main reason for 
this is lower labor costs but there is also another important factor: Poles willingly engage in work that "ethnic Germans" would not, because, for example, it is not economically viable for them: it does not pay enough. According to some experts, Germans are rarely hired by Poles because of culture and language barriers as well. The practice of hiring Germans by Poles is more common in commerce, where an effective sale is based on the awareness of the habits and mentality of potential German customers.

Employees from Germany [...] obviously work as salespeople or sales clerks in a given sales outlet. They also inspire greater confidence in a German client who reads certain cultural behaviors in a certain way. [...] If we wanted to sell a certain product having emotional aspects, [...] then it would be most appropriate if the seller is a German citizen, because he would empathize, so to speak, with a client from Germany, and could suggest solutions that would be good for this target group, and also, in some way, even empathetically behave in the context of the sales process, i.e. use a certain joke or make a situational reference to an event, or avoid using certain wording, because not in every cultural circle would the behavior of a Polish seller be considered adequate and appropriate in relation with the client. [R9]

The pattern of the choice of employees of a given nationality depend on the industrial sector. For example in construction, ethnic divisions are apparent. Germans commission the job and Poles are contractors or subcontractors. Relationships between Germans and Poles are reduced to business contacts; they do not go beyond the business area.

In business, however, the most important thing is money. If there is business to do, and if it is beneficial for both parties, even if we consider everything that is the worst and even though we perceive it through the prism of the past, stereotypes and other things, in the end, because we have a free market economy, in the end money wins. [R1]

The IT industry or, for example, the architectural industry are a little different. In those industries, cooperating people are highly educated, have better language skills and are more concerned about building a network of contacts, not only professional but also social. The Polish-German barriers in these business communities are much less apparent, and the nationality of co-worker or contractor does not matter much when the business objectives are successfully attained.

Here, it is worth comparing some characteristics of Polish entrepreneurs with those of their German counterparts. Both experts and entrepreneurs (we refer here to another part of this study) have directed our attention to this issue. First of all, Poles are more flexible and willing to multitask, meaning that, in contrast to their German co-workers who are very strict about their time, the Polish can work off-the-clock and on the weekends if necessary, without difficulties. If they are not going back to Poland for a weekend, they willingly take on extra work, which earns 
them extra money, pleases their customers, and might result in further benefits for the workers, including subsequent job orders and positive recommendations.

Generally there is one feature. This is not a field, but it is a trait that Poles and Polish entrepreneurs have, that is flexibility. And this is something that is just ... really a huge counterweight to the German character. Because Germans are indeed very precise and reliable and we can say a lot of positive things here, but they lack such flexibility and adaptation to changing conditions. Poles just have it, I have an impression, sometimes in their genes ... This is a huge advantage, because unfortunately, the economy is changing so often and you have to be prepared for it ... And the ease of Polish entrepreneurs to rearrange themselves, to revise some of their plans it is simply huge and this ... For example, German entrepreneurs do not have it at all. [R16]

Secondly, an added (and decreasingly significant) value of Polish entrepreneurs in Germany are their labor costs, lower than in case of employment of ethnic Germans. However, it turns out that the competitive advantage in the form of lower labor costs is not as important as the quality of products and services. In this area, Polish subcontractors win in comparison to other entrepreneurs and workers from Eastern Europe (Ukrainians, Romanians, and Bulgarians) whose work is cheaper but does not stand up in terms of quality.

Universality. Such an ability to commit, what they can do. In Poland, there is still no such specialization in industry as in Germany, that if someone specializes only, for example, in installation services, he only does this and does nothing else. And Poles are more flexible, also in terms of time: they work after hours, on weekends. The Germans do not overwork, they respect their free time, their attitudes also result from certain aspects of the legal system, the labor code, that they want to be free, that their employees want to be free. The Pole is trying to do everything to satisfy the employer and through these advantages, due to this flexibility, universality, can function in this market. Plus, of course, lower labor costs is the most important advantage of Poles. [R7]

However, one of the most important barriers slowing down the development of careers of Poles is still that of language - the factor emphasized in many studies as influencing the position of migrants in the job markets of receiving countries (see, e.g., Kloosterman and Rath 2003; Ram, Jones and Villares-Vareja 2017). A considerable number of foreign entrepreneurs, especially in the construction industry, do not speak German fluently. Over the course of years, they acquire language skills at a communicative level, or learn only industry-specific vocabulary, but cannot handle the official language of documents. They do not understand official letters well, which can result in problems with the law. They have to use the help of translators in communication with various institutions of public administration. Sometimes language skills are very important to relationships with customers and contractors. According to the interviewed experts, communication mediation 
between Polish and German businesspeople can disturb one-to-one communication or, in some cases, factor into to the failure of a business. Some of our respondents claim that the problem of unfamiliarity with the German language also concerns people in higher positions (for example chairpersons of companies) but in these cases, communication in English is sufficient.

Poles do not know German well, so they often need someone to help. Attorneys, project managers, managers who know the language can help them. Nevertheless, ignorance of the language is not an obstacle to starting a business, but it is in running it. They can't communicate with counterparties face to face, only through third parties who do not necessarily represent their interests. [R8]

I know many entrepreneurs who know German on the level of their industry, right? So if we're talking about home renovation, then the person knows how to say that I will renovate your wall, that I will replace the windows, that I will paint the wall, right? These are some key words. However, after some time, knowledge of the language is crucial, so that if I move the company to Germany, I will know what my communication with the office looks like, what should I say to the office, how should I refer to some arguments or to some possible allegations that the office presents to me, and how to possibly develop my business. [R9]

Another characteristic of the social capital in question is the ability to build social networks and relations based on weak or strong ties, in Mark Granovetter's sense. What is interesting, strong ties are more efficient in traditional businesses e.g. contraction, but in the IT sector, weak ties serve business development better (Granovetter 1973, 1974, 1983). Social networks of both types of ties are of increasing importance in today's economic activity, particularly concerning the transnational (see, e.g., Hannerz 1996; Vertovec 2009) (see also, Castells and Cardoso 2005, Brzozowski, Cucculelli and Surdej 2014).

Often the incentive to become self-employed in Germany is a consequence of the decisions of previous generations. The Poles who run companies in Berlin had usually arrived there with their parents, and sometimes siblings or friends, many years ago (usually meaning they are fluent and even proficient in German). They started their economic activity as full-time employees and after some time, after becoming well trained on-the-job and gaining sufficient experience, decided to set up their own businesses, becoming competition to their former employers. Such a scenario is very common for people in the construction and related industries. Having sufficient knowledge and skills, they set up their own businesses, believing this is a better way for them. Some of them felt exploited by their employers, which pushed them to work in their own right. The literature shows that one reason migrants set up businesses is discrimination. Our experts have suggested that sometimes Polish migrants are abused by their employers and so they seek 
refuge in self-employment. Often migrants, not only Poles in Germany, can feel pressure to run their own independent business instead of working a full-time job for somebody else (Vandor and Franke 2016).

Two categories of people can be distinguished. Running a business in Poland, having a company here and looking for contracts in Germany, then setting up a company in Germany, to lend credence to it, because Germans don't always want to cooperate with Poles, typically with Polish companies. A German address often looks better to them and inspires more confidence. And another category is of those people leaving Poland for Germany and transferring their family and professional life there. Polish construction companies provide services in Germany and their main center of life is there. It also happens that individual employees who as a rule do not initially run companies, but go to Germany to be employed, are forced to start a one-person business activity - if in such a situation one can talk about companies at all ... [R8]

The network of contacts in which the Polish entrepreneurs in Germany operate is an interesting phenomenon. Poles very often build ethnic enclaves, especially in Berlin. They are composed of families in similar situations. Migrants from Poland running businesses on the German market spend their free time together on weekdays, and free days and holidays in their home country. They miss their homeland and plan to return to Poland for retirement and/or when they achieve the economic status which allows them to maintain their new lifestyle and financially support their children in Poland.

Many entrepreneurs operate on the principle that they have their family in Poland, work here, invest in Poland, and simply in this way, in Poland they raise this standard of living much faster than working only in Poland. [R14]

In such small companies, it is rather everything in the Polish group. [R15]

Polish entrepreneurs are continuously building and maintaining social capital which results in advancement on the professional ground. They transfer the extra job orders to their compatriots, facilitate negotiations in public administration offices and expect the same from their Polish partners. Hence they do not need any special marketing strategy, because most of their job orders are acquired as a result of a recommendation system which prospers very well. It seems that the entrepreneurship of Poles in Germany is based on a system of in-group mutual recommendations and support.

That brings us to the third issue on the list of types of social capital: that of trust. In the context of discussions on the connections between entrepreneurship and culture, the opinions which influence the current background of Polish entrepreneurship in Germany - based on the historical-cultural past - are very interesting. It occurs from our interviews that at the beginning of the inflow of Poles into 
the German market they were treated with suspicion, although empirical cases of discrimination happened relatively rarely. Poles had to prove the value of their performance in order to be appreciated and deserve respect and confidence.

A German customer does not have such full confidence in Polish entrepreneurs. And it is completely different if an address like Berlin appears in the contact, something like the Strasse ... than, for example, Zielona Góra, street ... [R3]

In Germany, you must first show that you want to work well, and then Germans will work with you, really. [R1]

The above opinions refer to some stereotypes which should be broken down. We can find a similar situation in Finland (Aaltonen and Akola 2012). One of the most important barriers for immigrants is lack of trust, which is gained only gradually. The longer they stay in Finland and run a business, the better they are treated by the locals. This is closely tied to the language issue. Linguistic incompetence implicates distance and suspicion among the dominant population of the host society. It is very hard to change these situations without fluent communication.

The last issue in the general field of social capital derived from our analytical model is that of structural holes (Burt 1992). That aspect of social networking particularly favors those people who are transnational migrants, rather than the those settled in one country of destination. Considering the socio-geographical position of Berlin, one interesting issue is the constant movement of Polish entrepreneurs between their homeland and Germany. According to our experts, we can enumerate a few types of entrepreneurs according to their location and how they connect their working lives with the private sphere. Some of them have relocated to Germany with their families for good and they have reorganized their lives there. Still, some significant members of family and friends are left behind in Poland, so the migrants see their extended families only a few times a year, mostly during holidays. They are also connected with Poland by business contacts: subcontractors, counterparties, employees. Therefore, the total severing of personal relationships, or reduction of them to a minimum, takes place very rarely.

There are those who live here. They have their families here too, children go to school here, and it's just for them, at the moment, Neue Heimat, so to speak. And there are those who have a family in Poland, who, of course, they have to register here. I mean, because they run a business here, so they must also have a permanent address here. But they are more connected with Poland than here. They only keep their professional affairs in Germany. And there are those who actually work here. And they live here. [R14]

In the construction industry, Poles are already well-established here. As we say, let's say about staircases, it is known that these are staircases from Poland. As it is said about fences, there are fences from Poland. Whether it is a German who installed them, whether 
it is a Pole, whether it is a Turk, it does not matter, it's a Polish staircase. Because we are simply monopolists, because we make good staircases, because they are cheap. And transport across the border is not that expensive. [R14]

Another group of entrepreneurs is constantly moving between Poland and Germany: their personal life is based in the former country, while work and running companies occur in the latter. The males of this group are sometimes called "weekend daddies", since they spend working days abroad and alone, but weekends and holidays with their families in Poland, taking care of the children. They sometimes point towards the difficulties resulting from this lifestyle: exhaustion and longing for the family. Our interviewees talk about situations where Polish entrepreneurs, operating companies according to the German law, must have a business office and formal address in Germany, while in reality they manage their business from Poland. However, these are rare cases because nowadays frequent trips to Germany are not a practical problem thanks to modern logistics and road infrastructure.

I know entrepreneurs who during the week are several, a dozen times in Germany, commuting as if through Poland, right? As if we were going to Łódź or Warsaw, they are going the same way to Berlin, to Frankfurt, to Potsdam, to Hamburg, to Lübeck. Those are company owners who travel very often. [R9]

\section{Cognitive biases of the entrepreneurial activity of Poles in Germany}

The first characteristic of what are called cognitive biases in the model presented above is connected to the "over-confidence" of people setting up their own business in an environment unknown to them. This over-confidence has two faces: it could be taken as ignorance, or as accepting excessive risk. Many experts are of the opinion that a specific weakness of Polish entrepreneurs, and a barrier to their progress in Germany, is ignorance of the character of the market where they want to sell goods and services. Moreover, ignorance of the legal system leads to problems, and when they decide to set up a company with little awareness of German regulations and law, entrepreneurs know of them based only on information from other, allegedly more experienced Poles.

One of the problems, if somebody has established a business on the German market, in connection with running it, is ignorance of the regulations, right? Also, I would not identify problems here based on the assumption that there is something particularly difficult, but that something is unknown. And there is no awareness among Poles that this knowledge about the formal and real ways this market operates is relatively easily available. [R9] 
Sometimes German customers or contractors abuse the trust and non-culpable mistakes of Poles. Experts told us cases of breaching their confidence, provoking the administrative control of Polish companies, or deceiving Polish businesspeople who are unaware that they are making mistakes.

Lack of knowledge of the realities of the German market. They approach German partners, as if ignoring the principle of common sense, signing contracts without lawyers and signing unfavorable agreements. They have an approach: if something goes wrong, I will go back to Poland. They incorrectly estimate the costs and expected profits. [R8]

Interestingly, the wider the cognitive perspective of the entrepreneur, and the deeper and longer his perspective on his own experience, the more difficulties he points towards. In the course of time, the barriers do not fade away but seem to become more important. Quite often, Polish entrepreneurs see the problems and consider them significant only when they suddenly have to face them and solve them. Young entrepreneurs running a company for only a few years did not report many difficulties, and usually their over-confidence is still high.

The second trait of cognitive skills - the illusion of control - is also present among Polish entrepreneurs in Germany, according our respondents. Running a company in Germany has many advantages for Poles, but the question is whether there are negative aspects or difficulties with which they struggle on an everyday basis. It turns out that the answer is positive. Some of the difficulties are common to all entrepreneurs and can be found in most European countries to a similar extent. They are mentioned above: the necessity to learn and understand legal regulations and the procedures of successfully setting up an enterprise. Prospective entrepreneurs should know their formal obligations, for instance which fees have to be paid, and when and where, in order to avoid unnecessary audits or pecuniary penalties. A lot of entrepreneurs delegate these cognitive tasks to their accountants. They can rely on institutional support from public offices and private advisory companies that specialize in German economic law and offer assistance in finding useful interpretations of laws. However, in these situations the owner loses control over all aspects of running their own business.

Barriers arise if someone does not know the language, the law - then you might not be surprised. A lot of professions are regulated: it may turn out that a company must employ a person with a specific education and certificates. Often they do not realize this until the first inspection. [R8]

The final cognitive characteristic to discuss here is the "lack of representativity" of the everyday experience. Poles often point out that the German system is less oppressive in terms of the institutional-legal environment. Both the experts and entrepreneurs themselves believe that dealing with official matters in Germany is 
much faster and more entrepreneur-friendly than in Poland. In their opinions, the bureaucracy is not obstructive for them in Germany, while it discourages and irritates them in Poland. However, their experience is unrepresentative in the sense that it is limited only to the "success stories" - Polish companies which have made it on the German market.

Poles rarely use assistance at the start-up stage, unless it is a professional, large, experienced entity. They are looking for help mainly after the fact, for example when they can't get back the money. They can seek help from the embassy, but this is not detailed information. The embassy helps them to make contacts there. Poles exchange opinions on the Polish-German Internet forums and often this is the main source of information for them. They give up professional help mainly because of costs. [R8]

[For help] first, they turn to friends. To the wisest ones who tell them that ... [sigh], who have been in Germany for so long but, for example, they do not know that there is an obligation to insure themselves. [R10]

\section{Conclusion with the experts' future forecast}

Based on our interviews we would like to conclude with some possible future scenarios for the growth of entrepreneurial activity of Poles in Germany, in the eyes of our experts. Opinions about the future of Polish entrepreneurship in Germany differ. The experts hesitate to forecast, but, according to many of them, the situation can build up in two different directions. On the one hand, the industries in which Poles are establishing German companies are growing, and we can observe in Poland a very brisk movement of entrepreneurial activity toward the West.

I see the future of Polish entrepreneurship in Germany as very bright. [...] I would even say that I would be afraid for the Germans, [laugh] that there are so many Polish entrepreneurs who are simply very good, who are very effective [...]; it seems to me that they are looking for new niches and new opportunities all the time and are growing very well, I mean they do not focus only on their previous skills, but I really see that they are expanding a lot. [R16]

Experts draw attention to the clarity and stability of German regulations, which are friendlier than the increasingly unstable Polish legal environment toward entrepreneurs. Other great advantages are the spontaneity and creativity of Poles, which definitely aids the development and competitiveness of Polish entrepreneurship abroad.

Judging from the emails and telephones from Poland, from companies that are worried now, well ... new laws, that are to come into force in Poland, unified tax... health insurance 
for everyone, but in proportion to earnings. Some changes are to come. There are a lot of people who are seriously considering whether to first move to Germany and then to resettle the whole family. [R10]

On the other hand, there are some risks for Polish entrepreneurs in Germany, for example increasingly attractive conditions of full-time employment, which makes self-employment less worthwhile and more difficult. Some experts call into question the opinion that besides the relatively low labor costs of the Poles, Polish companies have other competitive advantages on the German market. Others, however, believe in the particularly high quality of Polish-produced goods and services. All stress the need for innovation as a feature that could help Polish entrepreneurship to grow. Polish entrepreneurs, if they want to succeed, should not only be contractors and subcontractors on the German labor market but also pioneers, creators and initiators.

It will grow, but in innovative industries, along with the increase in the wealth of the Poles. Over time, they will not undertake simple activities such as construction work or caregiving, because for a comparative amount of money they will be able to work in Poland. What are innovative industries? It's hard to say what will be innovative ... some inventions ... but there will be plenty of innovations, because we are constantly developing and progressing towards new ideas. In addition to innovations, we are competitive in the field of product quality. We produce in areas where the German economy does not work or operates minimally. We need something that the Germans will encourage; there must be a competitive advantage if we leave certain industries in which we show lower costs. [R8]

As we point out in our discussion, the general model of entrepreneurial opportunities presented above, referring to the social and cognitive embeddedness of this kind of economic activity, could be successfully implemented to the particular study of transnational entrepreneurship. It gave us the opportunity to look at entrepreneurial Poles in Germany from a slightly different perspective than those traditionally applied to the economic migration studies. Thanks to this model we were able to show that migrants have to cross many borders - state, language, culture, lifestyle, and legal - and that these borders have not disappeared but have become blurred with the passage of time, in the transnational context. The growing interconnectedness between EU countries, free flow of people and technological development will diminish migration barriers and will render these processes more visible.

\section{References}

Aaltonen S. and Akola E. (2012). Lack of trust - the main obstacle for immigrant entrepreneurship? http://pyk2.aalto.fi/ncsb2012/Aaltonen.pdf [July 2018]

Aldrich H.E. (2005) Entrepreneurship. In Smelser N.J. and Swedberg R (eds.) The Handbook of Economic Sociology. Princeton NJ: Princeton University Press, pp. 451-477. 
Aldrich H.E. and Martinez M. (2003) Entrepreneurship as Social Construction: A Multi-Level Evolutionary Approach. In Acs Z.J. and Audretsch D.B. (eds) Handbook of Entrepreneurship. Boston-Dordrecht-London: Kulwert Academic Publisher, pp. 359-399.

Aliaga-Isla, R. and Rialp, A. (2013). Systematic review of immigrant entrepreneurship literature: previous findings and ways forward. "Entrepreneurship and Regional Development", 25(9-10), pp. 819-844.

Bonacich E., (1973) Theory of Middleman Minorities. "American Sociological Review", 38, pp. 583-594.

Brzozowski J., Cucculelli M. and Surdej A., (2014) The determinants of transnational entrepreneurship and transnational ties' dynamics among immigrant entrepreneurs in ICT sector in Italy, https://www.uniba.it/ricerca/dipartimenti/dse/e.g.i/30Brzozowski.pdf [September 2018]

Burt R.S. (1992) Structural Holes: The Social Structure of Competition. Cambridge MA: Harvard University Press.

Castells M. and Cardoso G. (2005). The Network Society: From Knowledge to Policy. Washington DC: Johns Hopkins Center for Transatlantic Relations.

De Carolis D.M. and Saparito P. (2006). Social Capital, Cognition, and Entrepreneurial Opportunities: A Theoretical Framework, "Entrepreneurship: Theory and Practice", January, pp. 41-56.

Foreman-Peck, J. and Zhou, P. (2013). The strength and persistence of entrepreneurial cultures. "Journal of Evolutionary Economics", 23, pp. 163-187.

Garsztecki S. (2016). Pogranicze polsko-niemieckie: dotychczasowe osiągnięcia i wyzwania na przyszłość. In Niedźwiecki, D. (ed.). Pamięć i integracja społeczna na pograniczach. Przypadek pogranicza polsko-niemieckiego i polsko-ukraińskiego. Kraków: Zakład Wydawniczy NOMOS, pp. 13-32.

Granovetter M. (1973). The Strength of Weak Ties. "American Journal of Sociology", 78, pp. 1360$-89$.

Granovetter M. (1974). Getting a Job. A Study of Contacts and Careers. Cambridge MA: Harvard University Press.

Granovetter M. (1983). The Strength of Weak Ties. A Network Theory Revisited. "Sociological Theory" 1, pp. 201-233.

Hannerz, U. (1996). Transnational Connections. Culture, People, Places. London: Routledge.

Kloosterman, R. C. (2010). Matching opportunities with resources: A framework for analysing (migrant) entrepreneurship from a mixed embeddedness perspective. "Entrepreneurship and Regional Development", 22(1), pp. 25-45.

Kloosterman, R. and Rath, J. (2001). Immigrant entrepreneurs in advanced economies: mixed embeddedness further explored. "Journal of Ethnic and Migration Studies", 27(2), pp. 189-201.

Kloosterman R. and Rath J. (eds) (2003) Immigrant Entrepreneurs: Venturing Abroad in the Age of Globalization. Oxford: Berg.

Koźbiał K. (2015). Polsko-niemiecka współpraca zagraniczna wczoraj, dziś i jutro. Kilka uwag na marginesie “Strategii Rozwoju Polski Zachodniej 2020”. In Niedźwiecki D. (ed.) Pamięć i integracja społeczna na pograniczach. Przypadek pogranicza polsko-niemieckiego i polsko-ukraińskiego. Kraków: Zakład Wydawniczy NOMOS, pp. 33-48.

Lin X. and Tao S., (2012) Transnational entrepreneurs: Characteristics, drivers, and success factors, http://ccibd.ca/wp-content/uploads/2015/07/JIE-TE.pdf [September 2018] 
Nowicka M., (2013) Positioning Strategies of Polish Entrepreneurs in Germany: Transnationalizing Bourdieu's Notion of Capital, https://edoc.hu-berlin.de/bitstream/handle /18452/14257/27GinRDuatcT6.pdf?sequence=1 [September 2018]

Portes A. and Zhou M (1992). Gaining the Upper Hand: Economic Mobility among Immigrants and Domestic Minorities. "Ethnic and Racial Studies", 15, pp. 491-522.

Ram, M., Jones, T. and Villares-Varela, M. (2017). Migrant entrepreneurship: Reflections on research and practice. "International Small Business Journal", 35(1), pp. 3-18.

Reynolds P.D. (1991) Sociology and Entrepreneurship: Concepts and Contributions. "Entrepreneurship: Theory and Practice", 16, pp. 47-70.

Vandor, P., Franke, N., (2016). Why Are Immigrants More Entrepreneurial? https://hbr. org/2016/10/why-are-immigrants-more-entrepreneurial [July 2018]

Vertovec, S. (2009). Transnationalism. London: Routledge.

Waldinger R., Aldrich H.E. and Ward R. (1990). Ethnic Entrepreneurs. London: Sage. 